\title{
PERBANDINGAN MODEL PEMBELAJARAN PROBLEM POSING TIPE PRE SOLUTION DENGAN PEMBELAJARAN KONVENSIONAL DITINJAU DARI HASIL BELAJAR MATEMATIKA SISWA
}

\author{
Nisa Setiawati ${ }^{1}$, Rusdi ${ }^{2}$, Nurul Astuty Yensy $^{3}$ \\ 1,2,3 Program Studi Pendidikan Matematika JPMIPA FKIP Universitas Bengkulu \\ 1nisasetiawati29@gmail.com, ${ }^{2}$ rusdipendmat12@gmail.com, ${ }^{3}$ nurulastutyyensy@yahoo.com
}

\begin{abstract}
Abstrak
Penelitian ini bertujuan untuk mengetahui apakah hasil belajar matematika siswa antara pembelajaran Problem Posing Tipe Pre Solution lebih tinggi dibandingkan hasil belajar dengan pembelajaran konvensional di kelas VII SMP Negeri 2 Kota Bengkulu. Penelitian ini merupakan penelitian eksperimen dengan populasi penelitian ini adalah siswa kelas VII SMP Negeri 2 Kota Bengkulu. Sampel diambil dengan teknik purposive sampling sehingga diperoleh kelas eksperimen VII.D dengan jumlah 34 siswa yang menerapkan model pembelajaran problem posing tipe pre solution dan kelas kontrol VII.F dengan jumlah 34 siswa yang menerapkan pembelajaran konvensional. Berdasarkan hasil analisis data menggunakan uji $\mathrm{t}$ diperoleh $\mathrm{t}_{\text {hitung }}=2,047$ lebih dari nilai $\mathrm{t}_{\text {tabel }}=$ 1,9965 dalam taraf signifikan 5\%. Maka $\mathrm{H}_{0}$ ditolak sehingga dapat disimpulkan bahwa hasil belajar matematika siswa dengan menerapkan pembelajaran Problem Posing Tipe Pre Solution lebih tinggi dibandingkan dengan hasil belajar siswa dengan menerapkan pembelajaran konvensional di kelas VII SMP Negeri 2 Kota Bengkulu.

Kata Kunci : pembelajaran problem posing tipe pre solution, pembelajaran konvensional, hasil belajar

Abstract

This study aims to determine whether the results of learning mathematics students between learning Problem Posing Pre Solution Type is higher than the results of learning with conventional learning in class VII SMP Negeri 2 Kota Bengkulu. This research is an experimental research with population of this research is student of class VII SMP Negeri 2 Kota Bengkulu. The samples were taken by purposive sampling technique so that the experimental class VII.D was obtained with the number of 34 students applying the model of problem posing of pre-solution type and control class VII.F with 34 students applying conventional learning. Based on the results of data analysis using $t$ test obtained $t$ count $=2.047$ more than the value of ttable $=1.9965$ in a significant level of 5\%. Then $\mathrm{H}_{o}$ is $\mathrm{HO}$ rejected so it can be concluded that the results of learning mathematics students by applying learning Problem Posing Pre Solution Type is higher than the student learning outcomes by applying conventional learning in class VII SMP Negeri 2 Kota Bengkulu.
\end{abstract}

keywords: problem posing learning pre solution type, conventional learning, learning outcomes

\section{PENDAHULUAN}

Matematika merupakan salah satu ilmu yang sangat penting dalam kehidupan kita. Menurut Hudojo (2005:35) matematika sangat diperlukan untuk kehidupan sehari-hari maupun dalam menghadapi kamajuan IPTEK. Akan tetapi banyak siswa yang mengeluh ketika mempelajari matematika. Mereka menganggap matematika merupakan pelajaran yang sulit sehingga tidak banyak siswa yang menyukai mata pelajaran ini. Matematika dianggap sulit oleh siswa karena banyaknya rumus, konsep serta perhitungan yang harus mereka pelajari, apalagi jika ditambah dengan guru yang kurang bisa memahami karakter siswanya sehingga siswa menjadi semakin tidak senang untuk mempelajarinya.

Berdasarkan hasil observasi yang dilakukan di SMP N 2 Kota Bengkulu, terdapat 
beberapa permasalahan yang dihadapi dalam proses pembelajaran matematika : (1) guru masih mendominasi sehingga siswa hanya sekedar menerima materi; (2) siswa sibuk menyalin apa yang ditulis dan diucapkan oleh suru; (3) siswa terkadang terlihat asik sendiri ketika guru sedang menjelaskan materi pembelajaran; (4) siswa mengerjakan soal-soal latihan jika guru memberikan latihan soal tanpa berinisiatif sendiri untuk mengejakan soal-soal yang berkaitan dengan materi yang dipelajari.

Untuk memperbaiki kondisi diatas, guru perlu melakukan berbagai usaha, diantaranya adalah melakukan pembaharuan pada model pembelajaran. Salah satu model yang dapat digunakan adalah pembelajaran model Problem Posing. Menurut Ngalimun (2014:164) "Problem Posing adalah pemecahan masalah dengan melalui elaborasi, yaitu merumuskan kembali masalah menjadi bagian-bagian yang lebih simpel sehingga dipahami”. Model pembelajaran Problem Posing merupakan salah satu model pembelajaran yang melibatkan siswa secara aktif dalam proses kegiatan belajar mengajar dan siswa dilatih untuk memperkuat konsep-konsep dasar matematika.

Dalam pembelajaran Problem Posing guru menjelaskan materi pelajaran kepada siswa kemudian guru memberikan latihan soal yang berbentuk informasi, siswa diminta mengajukan soal yang menantang dan siswa yang bersangkutan harus mampu menyelesaikannya. Pengajuan masalah ini akan membantu siswa untuk termotivasi dan aktif dalam pembelajaran.

Pada model pembelajaran Problem Posing terdapat beberapa kelebihan yaitu : (1) mendidik murid berpikir kritis; (2) siswa aktif dalam pembelajaran; (3) belajar menganalisi suatu masalah; (4) mendidik anak percaya pada diri sendiri. Penelitian ini akan melihat pengaruh pendekatan Problem Posing Tipe Pre Solution terhadap hasil belajar matematika siswa. Problem Posing Tipe Pre Solution merupakan pembuatan soal dari situasi yang diadakan. Dalam model pembelajaran Problem Posing Tipe Pre Solution diawali dengan guru menerangkan dan memberikan contoh soal, tetapi pada saat latihan guru hanya memberi soal, sedangkan pertanyaan dan jawaban dari soal itu dibuat oleh siswa sendiri. Problem Posing Tipe Pre Solution merupakan salah satu model pembelajaran yang melibatkan siswa secara aktif dalam proses kegiatan belajar mengajar. Uraian latar belakang diatas mendorong penulis untuk melakukan penelitian dengan judul "Perbandingan Model Pembelajaran Problem Posing Tipe Pre Solution Dengan Konvensional Ditinjau dari Hasil Belajar Siswa Kelas VII SMP N 2 Kota Bengkulu Tahun Pelajaran 2016/2017”.

\section{METODE PENELITIAN}

\section{Jenis Penelitian}

Jenis penelitian yang akan dilaksanakan pada penelitian ini adalah penelitian quasi eksperimen. Menurut Sugiyono (2015: 77) quasi eksperimen adalah penelitian yang mempunyai kelompok kontrol, tetapi tidak dapat berfungsi sepenuhnya untuk mengontrol variabel-variabel luar yang mempengaruhi pelaksanaan eksperimen.

Pada kelas sampel pertama (kelas eksperimen) pembelajaran dilaksanakan dengan menggunakan model pembelajaran kooperatif tipe Group Investigation dan pada kelas sampel kedua (kelas kontrol) pembelajaran dilaksanakan dengan model pembelajaran kooperatif tipe STAD.

\section{Subjek Penelitian}

Subjek pada penelitian ini adalah seluruh siswa kelas VII di SMP Negeri 2 Kota Bengkulu, yang selanjutnya di pilih dua kelas yang homogen untuk dijadikan sampel.

\section{Teknik Pengumpulan Data}

Data yang digunakan dalam penelitian ini untuk mengukur tingkat kemampuan pemahaman konsep matematika yaitu dengan menggunakan instrumen postes. Postesd iberikan untuk kelas eksperimen yang menerapkan model pembelajaran problem posing tipe pre solution dan kelas kontrol yang menerapkan pembelajaran konvensional. Skor diberikan sesuai dengan tingkat pencapaian berdasarkan jawaban yang diberikan siswa dalam lembar jawaban setelah siswa mengerjakan soal.

Sebelum postes digunakan, terlebih dahulu dilakukan analisis item dengan uji validitas, 
reliabilitas, dan taraf kesukaran serta daya pembeda. Dengan hasil sebagai berikut:

Tabel 1 Hasil uji instrumen

\begin{tabular}{|c|c|c|c|c|c|}
\hline $\begin{array}{l}\text { No } \\
\text { Soal }\end{array}$ & $\begin{array}{c}\text { UjiVal } \\
\text { ditas }\end{array}$ & $\begin{array}{l}\text { jujiRea } \\
\text { bilitas }\end{array}$ & $\begin{array}{c}\text { UjiTar } \\
\text { afKesu } \\
\text { karan }\end{array}$ & $\begin{array}{l}\text { UjiDa } \\
\text { yaPem } \\
\text { beda }\end{array}$ & $\begin{array}{c}\text { Keteran } \\
\text { gan }\end{array}$ \\
\hline 1 & Valid & \multirow{5}{*}{$\begin{array}{c}\text { Seda } \\
\text { ng }\end{array}$} & Sedang & $\begin{array}{c}\text { Sedan } \\
\mathrm{g}\end{array}$ & $\begin{array}{c}\text { Diguna } \\
\text { kan }\end{array}$ \\
\hline 2 & Valid & & Sedang & $\begin{array}{c}\text { Sedan } \\
\mathrm{g}\end{array}$ & $\begin{array}{c}\text { Diguna } \\
\text { kan }\end{array}$ \\
\hline 3 & Valid & & Sedang & $\begin{array}{c}\text { Sedan } \\
\mathrm{g}\end{array}$ & $\begin{array}{c}\text { Diguna } \\
\text { kan }\end{array}$ \\
\hline 4 & Valid & & Sedang & $\begin{array}{c}\text { Sedan } \\
\mathrm{g}\end{array}$ & $\begin{array}{c}\text { Diguna } \\
\text { kan }\end{array}$ \\
\hline 5 & Valid & & Sedang & Baik & $\begin{array}{c}\text { Diguna } \\
\text { kan }\end{array}$ \\
\hline
\end{tabular}

Berdasarkan tabel di atas diperoleh bahwa keempat soal yang diujicobakan dapat digunakan sebagai postes, karena telah memenuhi kriteria penerimaan keempat uji yang dilakukaan.

\section{Teknik Analisis Data}

\subsection{Pengujian Persyaratan Analisis}

\subsubsection{Uji Normalitas}

Rumus yang digunakan:

$$
x^{2}=\sum \frac{\left(f_{0}-f_{h}\right)^{2}}{f_{h}}(\text { Sugiyono, 2012:19) }
$$

\subsubsection{Uji Homogenitas}

Uji homogenitas menggunakan Uji Bartlett. Kriteria pengujian: Tolak $\mathrm{H}_{0}$ yang menyatakan varians skornya homogen jika $x^{2} \geq x_{(1-\alpha)(d k)}^{2}$ (Sudjana, 2005: 263).

\subsection{Berdistribusi Normal}

\subsubsection{Pengujian Hipotesis}

$H_{0}: \mu_{1}=\mu_{2}$ (Tidak terdapat perbedaan yang signifikan antara kemampuan pemahaman konsep matematika siswa dengan model pembelajaran problem posing tipe pre solution dengan pembelajaran konvensional di Kelas VII SMP Negeri 2 Kota Bengkulu

$H_{1}: \mu_{1} \neq \mu_{2} \quad$ (Terdapat perbedaan yang signifikan antara kemampuan pemahaman konsep matematika siswa dengan model pembelajaran problem posing tipe pre solution dengan pembelajaran konvensional di Kelas VII SMP Negeri 2 Kota Bengkulu)
Pengujian hipotesis dilakukan dengan menggunakan uji-t. pengujian dilakukan dengan $\alpha=0,05$ dan derajat kebebasan $(\mathrm{dk})=$ $\left(\mathrm{n}_{1}+\mathrm{n}_{2}-2\right)$. Rumus uji-t yang digunakan adalah :

$$
t=\frac{\overline{x_{1}}-\overline{x_{2}}}{\sqrt{\frac{\left(n_{1}-1\right) s_{1}^{2}+\left(n_{2}-1\right) s_{2}^{2}}{n_{1}+n_{2}-2}\left(\frac{1}{n_{1}}+\frac{1}{n_{2}}\right)}}
$$

(Sugiyono, 2012: 138)

\section{HASIL DAN PEMBAHASAN}

A. HASIL

\section{Uji Normalitas}

Hasil uji normalitas data hasil belajar kedua kelas menggunakan uji chi square di sajikan pada tabel berikut:

Tabel 2 Hasil perhitungan dengan uji chi

\begin{tabular}{|c|c|c|c|}
\hline \multicolumn{4}{|c|}{ square } \\
\hline Kelas & $x_{\text {hitung }}^{2}$ & $x_{\text {tabel }}^{2}$ & Keterangan \\
\hline Eksperimen & 6,797 & 9,488 & $\mathrm{H}_{0}$ diterima \\
\hline Kontrol & 8,346 & 9,488 & $\mathrm{H}_{0}$ diterima \\
\hline \multicolumn{4}{|c|}{ (Sumber: lampiran 16 dan 17) }
\end{tabular}

Dari tabel di atas, dapat dilihat bahwa pada kelas eksperimen hasil $x_{\text {hitung }}^{2}=6,797 \leq$ $x_{\text {tabel }}^{2}=9,488$, sehingga $\mathrm{H}_{0}$ diterima. Jadi, data pada kelas eksperimen berdistribusi normal.

Pada kelas kontrol hasil $x_{\text {hitung }}^{2}=8,346 \leq$ $x_{\text {tabel }}^{2}=9,488$, sehingga $\mathrm{H}_{0}$ diterima. Jadi, data pada kelas kontrol berdistribusi normal.

\section{Uji Homogenitas}

Uji homogenitas dilakukan dengan Uji Bartlett, adapun hipotesisnya sebagai berikut:

$\mathrm{H}_{0}: \sigma_{1}^{2}=\sigma_{2}^{2}$ (data homogen)

$\mathrm{H}_{1}: \sigma_{1}^{2} \neq \sigma_{2}^{2}$ (data tidak homogen)

Kriteria pengujiannnya adalah terima $\mathrm{H}_{0}$ jika $x_{\text {hitung }}^{2} \leq x_{\text {tabel }}^{2}$, dalam kondisi yang lain maka $\mathrm{H}_{0}$ ditolak. Adapun hasil perhitungan menggunakan uji Bartlett di sajikan pada tabel berikut:

Tabel 3 Hasil perhitungan dengan uji Bartlett

\begin{tabular}{|c|c|l|}
\hline$x_{\text {hitung }}^{2}$ & $x_{\text {tabel }}^{2}$ & Keterangan \\
\hline 1,32 & 1,84 & $\mathrm{H}_{0}$ diterima \\
\hline \multicolumn{3}{|c}{ (Sumber: lampiran 18$)$} \\
\hline
\end{tabular}

Dari tabel di atas, dapat dilihat bahwa hasil perhitungan dengan uji Bartlett adalah $x_{\text {hitung }}^{2}=1,32 \leq x_{\text {tabel }}^{2}=1,84$, sehingga $\mathrm{H}_{0}$ 
diterima. Jadi, data pada kedua sampel homogen yang berarti bahwa nilai varians pada kedua kelas tersebut tidak jauh berbeda.

\section{a. Hasil Pengujian Hipotesis}

Karena data berdistribusi normal dan homogen, maka pengujian hipotesis dilakukan dengan menggunakan uji $t$ untuk sampel independen. Adapun hipotesis yang akan di uji adalah sebagai berikut:

$H_{0}: \mu_{1}=\mu_{2}$ (Rata-rata hasil belajar matematika siswa menggunakan pembelajaran Problem Posing Tipe Pre Solution sama dengan rata-rata hasil belajar matematika siswa menggunakan pembelajaran Konvensional di kelas VII SMPN 02 Kota Bengkulu)

$H_{1}: \mu_{1} \neq \mu_{2} \quad$ (Rata-rata hasil belajar matematika siswa menggunakan pembelajaran Problem Posing Tipe Pre Solution lebih tinggi dari rata-rata hasil belajar matematika siswa menggunakan pembelajaran Konvensional di kelas VII SMPN 02 Kota Bengkulu)

Kriteria pengujian hipotesis adalah jika nilai $-t_{\alpha / 2} \leq \mathrm{t}_{\text {hitung }} \leq t_{\alpha / 2}$ maka $\mathrm{H}_{0}$ diterima. Dan sebaliknya, jika $-t_{\alpha / 2}<t_{\text {hitung }}$ atau $t_{\text {hitung }}>t_{\alpha / 2}$ maka $\mathrm{H}_{0}$ ditolak. Adapun hasil perhitungan dengan uji $\mathrm{t}$ untuk sampel independen disajikan pada tabel berikut:

Tabel 4 Hasil perhitungan dengan uji $t$

\begin{tabular}{|c|c|l|}
\hline$t_{\text {hitung }}$ & $t_{\text {tabel }}$ & Keterangan \\
\hline 2,047 & 1,9965 & $\mathrm{H}_{0}$ ditolak \\
\hline
\end{tabular}

(Sumber: lampiran 19)

Dari tabel di atas dapat dilihat bahwa hasil perhitungan dengan uji t untuk sampel independen $\quad t_{\text {hitung }}=2,047 \geq t_{\text {tabel }}=$ 1,9965, sehingga $\mathrm{H}_{0}$ ditolak. Jadi dapat disimpulkan bahwa rata-rata hasil belajar matematika siswa menggunakan pembelajaran Problem Posing Tipe Pre Solution lebih tinggi dari rata-rata hasil belajar matematika siswa menggunakan pembelajaran Konvensional di kelas VII SMPN 02 Kota Bengkulu.

\section{B. PEMBAHASAN}

\section{B.1 Analisis Hasil Belajar}

Hasil penelitian ini menunjukkan bahwa hasil belajar matematika siswa yang pembelajarannya menggunakan pendekatan Problem Posing Tipe Pre Solution lebih tinggi dari hasil belajar matematika siswa yang pembelajarannya menggunakan pembelajaran Konvensional di SMPN 02 Kota Bengkulu pada materi persegi dan persegi panjang baik secara deskriptif maupun secara pengujian hipotesis. Hasil analisis deskriptif menunjukkan bahwa nilai rata-rata hasil belajar matematika siswa yang menggunakan pembelajaran Problem Posing Tipe Pre Solution lebih tinggi dari rata-rata hasil belajar matematika siswa yang menggunakan pembelajaran Konvensional yaitu 71,65 untuk kelas eksperimen dan 66,00 untuk kelas kontrol.

Perolehan nilai maksimum dan minimum pada kedua kelas yaitu nilai maksimum dan nilai minimum pada kelas eksperimen berturut-turut adalah 95 dan 50 sedangkan nilai maksimum dan minimum pada kelas kontrol berturut-turut adalah 90 dan 50 . Pada kelas eksperimen terdapat 13 siswa yang telah memenuhi kriteria ketuntasan minimum dan 21 siswa yang belum memenuhi kriteria ketuntasan minimum, sedangkan kelas kontrol terdapat 6 siswa yang telah memenuhi kriteria ketuntasan minimum dan 28 siswa yang belum memenuhi kriteria ketuntasan minimum.

Ada beberapa factor yang menyebabkan siswa tidak dapat mencapai kriteria ketuntasan minimum pada tes akhir, diantaranya siswa tidak memperhatikan pada saat guru menjelaskan, siswa kurang mempersiapkan diri dalam menghadapi tes, siswa belum menguasai materi pelajaran, siswa kurang teliti dalam mengerjakan soal tes.

Secara umum, berdasarkan data hasil belajar dapat dilihat bahwa hasil belajar menggunakan pembelajaran problem posing tipe pre solution lebih tinggi dari hasil belajar menggunkan pembelajaran konvensional. Hal ini sesuai dengan pendapat Throbroni (2015) yang menyatakan bahwa model pembelajaran problem posing tipe pre solution dapat memantapkan kemampuan belajar siswa, 
mendidik siswa berpikir kritis, belajar menganalisis suatu masalah, mendidik anak percaya diri sendiri, dengan adanya pembuatan soal sekaligus jawaban dari informasi yang ada dapat menyebabkan ingatan siswa jauh lebih baik, sehingga dapat meningkatkan hasil belajar.

Disamping itu, hasil analisis saat siswa menjawab soal proses juga terlihat dimana untuk kelas eksperimen rata-rata siswa sudah terbiasa menjawab dengan terstruktur, dimulai dari apa yang diketahui dari apa yang diketahui dari soal, apa yang ditanya, dan penyelesaiannya, hingga kesatuan nilai akhirnya. Hal ini terlihat dari nilai hasil tes akhir yang diperoleh pada kelas eksperimen mmemiliki rata-rata lebih tinggi dibanding kelas kontrol. Sehingga dapat dikatakan bahwa apabila siswa diajar dengan menggunakan pembelajaran Problem Posing Tipe Pre Solution dapat meningkatkan hasil belajar.

Berdasarkan analisis deskriptif yang telah diperoleh dapat disimpulkan hasil belajar matematika siswa yang diajar dengan pembelajaran Problem Posing Tipe Pre Solution lebih tinggi dibandingkan hasil belajar matematika siswa yang diajar dengan pembelajaran Konvensional. Selanjutnya hasil uji hipotesis mendukung secara signifikan. Terlihat dari hasil perhitungan $t_{\text {hitung }}=2,047>$ $\mathrm{t}_{\text {tabel }}=1,9965$ dengan $\alpha=5 \%$. Sehingga menunjukkan bahwa hasil belajar matematika siswa yang pembelajarannya menggunakan pembelajaran Problem Posing Tipe Pre Solution lebih tinggi dibandingkan hasil belajar matematika siswa yang pembelajarannya menggunakan pembelajaran Konvensional.

Hasil penelitian ini menunjukkan bahwa pentingnya guru dalam menggunakan pembelajaran Problem Posing Tipe Pre Solution. Dalam kegiatan pembelajaran jika guru terus-menerus menggunakan pembelajaran konvensional maka siswa akan merasa bosan dan menjadi tidak menyukai pembelajaran matematika. Salah satu pembelajaran yang dapat digunakan guru adalah menggunakan pembelajaran Problem Posing Tipe Pre Solution. Dengan menggunakan pembelajaran Problem Posing Tipe Pre Solution, menyebabkan siswa mengarahkan kegiatan belajar dengan melibatkan akalnya dan termotivasi sendiri dan dapat mengembangkan bakatnya sehingga mendorong siswa berfikir dan bekerja atas inisiatif sendiri yang dapat mengembangkan bakatnya sendiri dan hasil belajar siswa pun meningkat.

\section{SIMPULAN DAN SARAN}

\section{A. Simpulan}

Berdasarkan hasil penelitian, maka dapat disimpulkan bahwa rata-rata hasil belajar matematika siswa menggunkan pembelajaran Problem Posing Tipe Pre Solution lebih tinggi dari rata-rata hasil belajar matematika siswa menggunakan pembelajaran konvensional di kelas VII SMPN 02 Kota Bengkulu. Hal ini ditunjukkan dari hasil uji statistik yaitu uji-t dengan niali $\mathrm{t}_{\text {hitung }}=2,047>\mathrm{t}_{\text {tabel }}=1,9965$, maka $\mathrm{H}_{0}$ ditolak. Nilai rata-rata hasil belajar siswa kelas eksperimen lebih tinggi dari kelas kontrol.

\section{B. Saran}

Saran yang dapat dikemukakan berdasarkan hasil penelitian yang telah dilakukan adalah:

1. Diharapkan pada guru bidang studi matematika di SMPN 02 Kota Bengkulu ataupun sekolah lainnya untuk dapat menerapkan pembelajaran Problem Posing Tipe Pre Selution sebagai salah satu alternative untuk meningkatkan hasil belajar matematika siswa dan mengaktifkan siswa dalam belajar.

2. Melihat hasil belajar yang diperoleh siswa meningkat dalm mempelajari poko bahasan persegi dan persegi panjang dengan menggunakan model pembelajaran Problem Posing Tipe Pre Solution, disarankan suapaya dilakukan penelitian lebih lanjut pada pokok bahasan lain dan diharapkan dapat menjadikan siswa aktig dalam proses pembelajaran. 


\section{DAFTAR PUSTAKA}

Hamzah, M.A, \& Muhlisrarini. (2014) Perencanaan dan Strategi Pembelajaran Matematika, Jakarta, Rjawali Pers

Hudojo, H. (2005). Pengembangan Kurikulum dan Pembelajaran Matematika. Malang: Universitas Negeri Malang

Ngalimun. (2011). Strategi dan Model Pembelajaran, Yogyakarta, Aswaja Pressindo

Ruseffendi. (1991). Pengantar Kepada Membantu Guru Mengembangkan Kompentensinya dalam Pengajaran Matematika untuk Meningkatkan CBSA. Bandung: Tarsito
Suryabrata, S. (2003). Metodologi Penelitian. Jakarta: PT Raja Grafindo Persada

Slameto. (2010). Belajar dan Faktor-Faktor yang Mempengaruhi, Jakarta, Rineka Cipta

Sudijono, A. (2008). Pengantar Evaluasi Pendidikan. Jakarta: PT Raja Grafindo Persada.

Sugiyono. (2015). Memahami Penelitian Kualitatif. Bandung: Alfabet

Sudjana. 2005. Metoda Statistika. Bandung: Tarsito

Sugiyono. 2012. Statistik untuk Penelitian. Bandung: CV Alfabeta

Thobroni, M. (2015) Belajar dan Pembelajaran, Yogyakarta, Ar-Ruzz Media 